\title{
Chemical and Biological Management of Leaf Spot and Flower Blight of Marigold
}

\begin{abstract}
T. Anand
Department of Plant Pathology, Tamil Nadu Agricultural University, Coimbatore, Tamil Nadu, India

Corresponding author: anandpath10@yahoo.com (ORCID ID: 0000-0001-8230-4494)
\end{abstract}

Paper No. 926

Received: 04-06-2021

Revised: $25-08-2021$

Accepted: 06-09-2021

\begin{abstract}
Marigold (Tagetes erecta L.) is an important commercial and garden flower crop. Alternaria leaf spot and Botrytis flower blight are the significant constraints in marigold cultivation. In this study, different bioagents and fungicides were tested for their efficacy against leaf spot and flower blight of marigold under field conditions. Among the bioagents tested, seed treatment $(1 \%)+$ foliar spray $(0.2 \%)$ of Pseudomonas (TNAU-Pf1) at 30 and 45 days after planting (DAP) was found to be effective in controlling Alternaria leaf spot and Botrytis flower blight and also recorded higher flower yield compared to other bioagents. Among the fungicides tested, seed treatment $(0.2 \%)+$ foliar spray of hexaconazole + zineb $(0.2 \%)$ was found effective in reducing the incidence of both diseases and recorded higher flower yield followed by pyraclostrobin + metiram $(0.2 \%)$.

\section{HIGHLIGHTS}

(- Hexaconazole + zineb and pyraclostrobin-metiram were the best fungicides for effectively managing Alternaria leaf spot and Botrytis flower blight of marigold.

(- Among the bioagents, Pseudomonas (TNAU-Pf1 was found to be effective in controlling leaf spot and flower blight disease.
\end{abstract}

Keywords: Bioagents, flower blight, fungicides, leaf spot, marigold

Marigold (Tagetes erecta L.) is one of the important commercially cultivated flower crops grown in various agroclimatic regions of India. Growth and yield of marigold are affected by various foliar fungal diseases. Among them, leaf spot incited by Alternaria tagetica and flower blight caused by Botrytis cinerea has emerged as significant constraints compared to other diseases (Sen 1996; Chandel et al. 2010). There are many disease control methods, but in general, chemical and biological methods are considered the most effective and reliable. Recently, new fungicide molecules have been used to control a wide range of pathogens in different flower crops. Dithane M-45, carbendazim and hexaconazole can control Alternaria leaf spot and flower blight disease in marigold and other ornamental flower crops (Shindhe et al. 2018; Aktar and Shamsi 2015; Singh et al. 2012; Bharnwal et al. 2002).
Similarly, a large number of plant diseases have been successfully controlled through bacterial and fungal antagonists (Cook and Baker 1983; Campbell 1989; Vidhyasekaran et al. 1997). Pseudomonas fluorescens (TNAU-Pf1), Bacillus subtilis (Bs1) and Trichoderma asperellum (Ta1) are the most effective biocontrol agents currently available at the Department of Plant Pathology, TNAU, Coimbatore and are used primarily for seed, soil and foliar treatment due to its efficient antagonistic activity against various plant pathogens (Vidhyasekaran et al. 1997; Ramamoorthy et al. 2002; Thilagavathi et al. 2007; Latha et al. 2009; Rakshit et al. 2018). Thus, in the

How to cite this article: Anand, T. 2021. Chemical and Biological Management of Leaf Spot and Flower Blight of Marigold. IJAEB, 14(03): 399-403.

Source of Support: None; Conflict of Interest: None (क) 
present study, the objective was to investigate the effect of selected bioagents and fungicides as seed treatment and foliar application against Alternaria leaf spot and Botrytis flower blight of marigold under field conditions.

\section{MATERIALS AND METHODS}

\section{Biocontrol agents}

The isolates of Pseudomonas fluorescens (TNAUPf1), Bacillus subtilis (Bs1), Trichoderma asperellum (Ta1) were obtained from the Culture Collection Section, Department of Plant Pathology, Tamil Nadu Agricultural University (TNAU), Coimbatore, India.

\section{Preparation of talc-based bioformulation}

A loopful of P. fluorescens and B. subtilis was inoculated into sterilized King's B and Nutrient broth, respectively and incubated in a rotary shaker at $150 \mathrm{rpm}$ for $48 \mathrm{~h}$ at room temperature $(28 \pm 2$ $\left.{ }^{\circ} \mathrm{C}\right)$. After $48 \mathrm{~h}$ of incubation, the broth containing $9 \times 10^{8} \mathrm{cfu} / \mathrm{ml}$ was used to prepare talc-based formulation. To the $400 \mathrm{ml}$ of bacterial suspension, $1 \mathrm{~kg}$ of the talc powder (sterilized at $105{ }^{\circ} \mathrm{C}$ for $12 \mathrm{~h}$ ), calcium carbonate $15 \mathrm{~g}$ (to adjust the $\mathrm{pH}$ to neutral) and carboxymethyl cellulose (CMC) $10 \mathrm{~g}$ (adhesive) were mixed under sterile conditions, following the method described by Nandakumar et al. (2001). After shade drying overnight, it was packed in a polypropylene bag and sealed. At the time of application, the population of bacteria in talc formulation was $2.5-3 \times 10^{8} \mathrm{cfu} / \mathrm{g}$.

Trichoderma asperellum isolate was multiplied in molasses-yeast broth (30 ml molasses; 5 g yeast; 11 distilled water). The sterile broth was inoculated with an actively growing mycelial disc $(8 \mathrm{~mm})$ incubated for 10 days. The biomass $\left(3 \pm 10^{8} \mathrm{cfu} / \mathrm{ml}\right)$ and the medium were incorporated into the sterilized talc powder at the rate of $50 \mathrm{ml}$ of suspension per $100 \mathrm{~g}$ of talc powder and thoroughly mixed with $500 \mathrm{mg}$ CMC as described by Ramakrishnan et al. (1994).

\section{Effect of different bioagents and fungicides on leaf spot and flower blight of marigold under field conditions}

Two field experiments were carried out at Regional Research Station farm, Paiyur, during March 2015- June 2015 and August 2015-November 2015 to evaluate the efficacy of different bioagents and fungicides against Alternaria leaf spot and Botrytis flower blight of marigold. The treatments of the experiments were:

- T1- Seed Treatment (ST) $(1 \%)+$ Foliar spray of P. fluorescens -TNAU-Pf1 (0.5\%)

- T2- ST (1\%) + Foliar spray of B. subtilis -Bs1 $(0.5 \%)$

- T3- ST $(0.4 \%)+$ Foliar spray of T. asperellum-Ta1 $(0.5 \%)$

- T4- ST $(0.2 \%)+$ Foliar spray of Pyraclostrobin + metiram $(0.2 \%)$

- T5- ST $(0.2 \%)+$ Foliar spray of Thiophanate methyl $(0.1 \%)$

- T6- ST $(0.2 \%)+$ Foliar spray of hexaconazole + zeneb $(0.2 \%)$

- T7- Untreated control

The field experiment was laid out in a Randomized Block Design (RBD) with three replications using Maximum Yellow for the first season and Supreme Yellow for the second season. The individual plot size of $15 \mathrm{~m}^{2}$ was maintained and the seedlings were planted at a spacing of $60 \times 45 \mathrm{~cm}$.

\section{Method of application}

Before sowing, marigold seeds were treated with the talc-based formulation of bioagents and fungicides as per the treatment schedule. The talcbased formulation of bioagents and fungicides was applied 30 and 45 days after planting (DAP) using a high-volume backpack knapsack sprayer with a 500 lit/ha spray fluid. The seeds not treated with bacterial strains or fungicide served as control.

\section{Disease assessment}

The incidence of Alternaria leaf spot was recorded in different bioagents and fungicides sprayed plots using a standard score chart. It was based on the percentage of leaf area affected where 0 - No visible symptom, 1- 1 to $10 \%, 2-11$ to $20 \%, 3-21$ to $30 \%$, 431 to $40 \%$ and 5- 41 and above. The percent flower infection (blight) was also recorded after spraying the crop. The plant growth and yield attributes were also recorded in all the treatments.

\section{STATISTICAL ANALYSIS}

The data were subjected to analysis of variance (ANOVA) using the IRRISTAT version 92-1 program 
developed by the Biometrics Unit, International Rice Research Institute, The Philippines. Disease incidence data were arc-sine transformed before analysis. The treatment means were compared by Duncan's multiple range test (DMRT) (Gomez and Gomez 1984).

\section{RESULTS AND DISCUSSION}

Among the three biocontrol agents tested the use of P. fluorescens (TNAU-Pf1) was proved to be best in reducing both Alternaria leaf spot and Botrytis flower blight incidence, i.e., seed treatment (1\%) and foliar spray $(0.5 \%)$ of TNAU-Pf1 at 30 and 45 days after planting recorded only 3.20 PDI of leaf spot and $3.73 \%$ of flower blight. Among the fungicides, seed treatment $(0.2 \%)+$ foliar spray of hexaconazole + zeneb $(0.2 \%)$ and ST $(0.2 \%)+$ foliar spray of pyraclostrobin + metiram $(0.2 \%)$ recorded only 0.88 and 1.47 PDI of leaf spot and 1.64 and $1.85 \%$ of flower blight, respectively and both treatments were on par with each other. Maximum incidence of 13.33, PDI of leaf spot and $15.77 \%$ of flower blight was observed in untreated control plots.
The experimental results on the growth and other yield attributes revealed that the highest plant height of $53.60 \mathrm{~cm}$ was recorded in TNAU- Pf1 (seed treatment+ foliar spray) treated plots followed by hexaconazole + zineb $(48.25 \mathrm{~cm})$ and pyraclostrobin + metiram $(47.92 \mathrm{~cm})$. Whereas hexaconazole + zineb and pyraclostrobin + metiram treated plots recorded higher no. of flowers/plant, flower yield and BC ratio compared to all other treatments recorded 60.67 and 59.67 no. /plant, 12.34 and 12.09 tonnes/ha and $\mathrm{BC}$ ratio of 2.9 and 2.7, respectively followed by TNAU-Pf1 (56.70 no./plant; 11.69 tonnes/ha; 1:2.7). Untreated control plots recorded the minimum plant height $(43.24 \mathrm{~cm})$, no. of flowers/plant (42.00) and flower yield (6.54 tonnes/ha).

In the second season also, seed treatment (1\%) and foliar spray $(0.5 \%)$ of TNAU-Pf1 at 30 and 45 DAP significantly reduced the incidence of Alternaria leaf spot (4.44 PDI) and Botrytis flower blight (4.96\%). Similarly, the fungicides hexaconazole + zineb and pyraclostrobin + metiram treated plots recorded only 2.12 and 2.47 PDI of leaf spot and 2.83 and $3.02 \%$ incidence of flower blight, respectively.

Table 1: Effect of bioagents and fungicides on the incidence of leaf spot and flower blight in marigold (Season I)

\begin{tabular}{llll}
\hline Sl. No. & Treatments & $\begin{array}{l}\text { Alternaria leaf spot } \\
\text { (PDI) }\end{array}$ & $\begin{array}{l}\text { Botrytis flower blight } \\
\text { (\%) }\end{array}$ \\
\hline 1 & P. fluorescens (ST @ 1\% and FS @ 0.5\%) & $3.20^{\mathrm{b}}$ & $3.73^{\mathrm{b}}$ \\
2 & B. subtilis (ST @ 1\% and FS @ 0.5\%) & $7.40^{\mathrm{c}}$ & $8.60^{\mathrm{d}}$ \\
3 & T. asperellum (ST @ 0.4\% and FS @ 0.5\%) & $8.87^{\mathrm{c}}$ & $9.59^{\mathrm{d}}$ \\
4 & Pyraclostrobin + metiram (ST @ 0.2\% and FS @ 0.2\%) & $1.47^{\mathrm{a}}$ & $1.85^{\mathrm{a}}$ \\
5 & Thiophanate methyl (ST @ 0.2 \% and FS @ 0.1\%) & $3.44^{\mathrm{b}}$ & $5.65^{\mathrm{b}}$ \\
6 & Hexaconazole + zineb (ST @ 0.2\% and FS @ 0.2\%) & $0.88^{\mathrm{a}}$ & $1.64^{\mathrm{a}}$ \\
7 & Untreated control & $13.33^{\mathrm{d}}$ & $15.77^{\mathrm{e}}$ \\
\hline
\end{tabular}

ST- Seed Treatment; FS- Foliar Spray; Values are means of three replications. In a column, means followed by a common letter are not significantly different at $5 \%$ level by DMRTs.

Table 2: Effect of bioagents and fungicides on growth and flower yield of marigold (Season I)

\begin{tabular}{|c|c|c|c|c|c|c|}
\hline $\begin{array}{l}\text { Sl. } \\
\text { No. }\end{array}$ & Treatments & $\begin{array}{l}\text { Plant Height } \\
(\mathrm{cm})\end{array}$ & $\begin{array}{l}\text { No. of } \\
\text { flowers/ plant }\end{array}$ & $\begin{array}{l}\text { Flower yield/ } \\
\text { plot }(\mathrm{Kg})\end{array}$ & $\begin{array}{l}\text { Flower yield } \\
\text { (tones/ha) }\end{array}$ & BCR \\
\hline 1 & P. fluorescens (ST @ 1\% and FS @ 0.5\%) & $53.60^{\mathrm{a}}$ & $56.70^{\mathrm{b}}$ & $12.16^{\mathrm{a}}$ & $11.69^{\mathrm{b}}$ & 2.7 \\
\hline 2 & B. subtilis (ST @ 1\% and FS @ 0.5\%) & $48.26^{\mathrm{b}}$ & $53.00^{c}$ & $10.13^{\mathrm{b}}$ & $9.74^{\mathrm{d}}$ & 2.2 \\
\hline 3 & T. asperellum (ST @ 0.4\% and FS@ 0.5\%) & $47.02^{\mathrm{bc}}$ & $50.67^{c}$ & $9.27^{c}$ & $8.91^{\mathrm{e}}$ & 2.0 \\
\hline 4 & $\begin{array}{l}\text { Pyraclostrobin + metiram (ST @ } 0.2 \% \text { and FS @ } \\
0.2 \% \text { ) }\end{array}$ & $47.92^{\mathrm{bc}}$ & $59.67^{\mathrm{a}}$ & $12.57^{\mathrm{a}}$ & $12.09^{\mathrm{ab}}$ & 2.7 \\
\hline 6 & $\begin{array}{l}\text { Hexaconazole + zineb (ST @ 0.2\% and FS @ } \\
0.2 \% \text { ) }\end{array}$ & $48.25^{\mathrm{b}}$ & $60.67^{\mathrm{a}}$ & $12.83^{\mathrm{a}}$ & $12.34^{\mathrm{a}}$ & 2.9 \\
\hline 7 & Untreated control & $43.24^{\mathrm{d}}$ & $42.00^{\mathrm{d}}$ & $6.80^{\mathrm{d}}$ & $6.54^{\mathrm{f}}$ & - \\
\hline
\end{tabular}

ST-Seed Treatment; FS- Foliar Spray; Values are means of three replications. In a column, means followed by a common letter are not significantly different at 5\% level by DMRTs. 
Table 3: Effect of bioagents and fungicides on the incidence of leaf spot and flower blight in marigold (Season II)

\begin{tabular}{llll}
\hline S1. No. & Treatments & $\begin{array}{l}\text { Alternaria leaf } \\
\text { spot (PDI) }\end{array}$ & $\begin{array}{l}\text { Botrytis flower blight } \\
\text { (\%) }\end{array}$ \\
\hline 1 & P. fluorescens (ST @1\% and FS @ 0.5\%) & $4.44^{\mathrm{b}}$ & $4.96^{\mathrm{b}}$ \\
2 & B. subtilis (ST @ 1\% and FS @ 0.5\%) & $7.90^{\mathrm{c}}$ & $8.33^{\mathrm{c}}$ \\
3 & T. asperellum (ST @ 0.4\% and FS @ 0.5\%) & $9.14^{\mathrm{d}}$ & $8.52^{\mathrm{c}}$ \\
4 & Pyraclostrobin+ metiram (ST @ 0.2\% and FS @ 0.2\%) & $2.47^{\mathrm{a}}$ & $3.02^{\mathrm{ab}}$ \\
5 & Thiophanate methyl (ST @ 0.2\% and FS @ 0.1\%) & $8.40^{\mathrm{cd}}$ & $4.84^{\mathrm{b}}$ \\
6 & Hexaconazole+ zineb (ST @ 0.2\% and FS @ 0.2\%) & $2.12^{\mathrm{a}}$ & $2.83^{\mathrm{a}}$ \\
7 & Untreated control & $16.05^{\mathrm{e}}$ & $18.34^{\mathrm{d}}$ \\
\hline
\end{tabular}

ST-Seed Treatment; FS- Foliar Spray; Values are means of three replications. In a column, means followed by a common letter are not significantly different at $5 \%$ level by DMRTs.

Table 4: Effect of bioagents and fungicides on growth and flower yield in marigold (Season II)

\begin{tabular}{|c|c|c|c|c|c|c|}
\hline $\begin{array}{l}\text { Sl. } \\
\text { No. }\end{array}$ & Treatments & $\begin{array}{l}\text { Plant Height } \\
\text { (cm) }\end{array}$ & $\begin{array}{l}\text { No. of flowers/ } \\
\text { plant }\end{array}$ & $\begin{array}{l}\text { Flower yield/ } \\
\text { plot (Kg) }\end{array}$ & $\begin{array}{l}\text { Flower yield/ } \\
\text { ha (tonnes) }\end{array}$ & BCR \\
\hline 1 & P. fluorescens (ST @ 1\% and FS @ 0.5\%) & $59.16^{\mathrm{a}}$ & $63.33^{c}$ & $11.97^{c}$ & $12.34^{\mathrm{c}}$ & 2.6 \\
\hline 2 & B. subtilis (ST @ 1\% and FS @ 0.5\%) & $51.99^{c}$ & $56.66^{\mathrm{e}}$ & $9.87^{\mathrm{d}}$ & $10.28^{\mathrm{e}}$ & 2.4 \\
\hline 3 & T. asperellum (ST@ 0.4\% and FS @ 0.5\%) & $53.59^{c}$ & $58.80^{\mathrm{d}}$ & $9.40^{\mathrm{d}}$ & $9.79^{\mathrm{f}}$ & 2.3 \\
\hline 4 & $\begin{array}{l}\text { Pyraclostrobin + metiram (ST @ 0.2\% and FS @ } \\
0.2 \% \text { ) }\end{array}$ & $58.66^{\mathrm{ab}}$ & $66.67^{\mathrm{b}}$ & $12.97^{\mathrm{b}}$ & $13.51^{\mathrm{b}}$ & 2.8 \\
\hline 5 & Thiophanate methyl (ST @ 0.2 \% and FS @ 0.1\%) & $52.67^{c}$ & $58.67^{\mathrm{d}}$ & $10.60^{c}$ & $11.04^{\mathrm{d}}$ & 2.4 \\
\hline 6 & Hexaconazole + zineb (ST @ 0.2\% and FS @ 0.2\%) & $57.90^{\mathrm{b}}$ & $68.67^{\mathrm{a}}$ & $14.53^{\mathrm{a}}$ & $15.14^{\mathrm{a}}$ & 3.1 \\
\hline 7 & Untreated control & $46.27^{\mathrm{d}}$ & $45.00^{f}$ & $7.53^{\mathrm{e}}$ & $7.85^{\mathrm{g}}$ & - \\
\hline
\end{tabular}

ST- Seed Treatment; FS- Foliar Spray; Values are means of three replications. In a column, means followed by a common letter are not significantly different at 5\% level by DMRTs.

The untreated control plot recorded a maximum leaf spot incidence (16.05 PDI) and flower blight (18.34\%).

The growth and flower yield data presented in table 4 revealed that TNAU-Pf1 treated plots recorded higher plant height $(59.16 \mathrm{~cm})$, no. of flowers/plant (63.33) and flower yield (12.34 tonnes/ha) and BC ratio (1:2.6) compared to other two bioagents tested. However, the fungicides hexaconazole + zineb and pyraclostrobin + metiram treated plots recorded a maximum no. of flowers/plant $(68.67 ; 66.67)$, flower yield $(15.14 ; 13.51$ tonnes/ha) and BC ratio (1:3.1; 1:2.8) compared to other treatments. Untreated control plot recorded only lesser no. of flowers/plant (45.00) and flower yield (7.85 tonnes/ha).

The present findings confirm those reported by Chandel et al. (2003 and 2010), who reported that the treatment of sulfur fungicide (mancozeb) gave better disease control of Alternaria leaf spot and flower blight in marigold. Shindhe et al. (2018) reported that hexaconazole $(0.1 \%)$ was found effective in reducing the incidence of leaf spot and flower blight of marigold and increased flower yield followed by mancozeb. Singh et al. (2006) also obtained maximum disease control and marigold flower yield by applying triazol compounds like difenoconazole and penconazole. Similarly, Li and $\mathrm{Wu}$ (2002) reported that triazole group fungicides gave better control of Alternaria blight in carnation.

\section{REFERENCES}

Aktar, M. and Shamsi, S. 2015. Blight of two species of marigold (Tagetes) caused by Aspergillus fumigatus Fresenius. Bangladesh J. Plant Pathol., 31(1\&2): 1-6.

Bharnwal, M.K., Jha, D.K. and Dubey, S.C. 2002. Evaluation of fungicides against Alternaria blight of marigold (Tagetes sp.). J. Res. Birsa Agril. University, 14(1): 99-100.

Campbell, R. 1989. Biological Control of Microbial Plant Pathogens. Cambridge University Press, Cambridge.

Chandel, D., Silva, J.A.T. and Sharma, C. 2010. Management of Alternaria leaf spot and flower blight of Marigold (Tagetes erecta L.) cv. Crackerjack by application of fungicides and neem formulation. Floriculture Ornamental Biotech. 4(Special issue 1): 79-83. 
Chandel, S.S., Kaur M. and Pathania, N. 2003. Effect of fungicide treatment on seed viability, seed mycroflora and plant health of marigold. J. Hill Res., 16(1): 29-31.

Cook, R.J. and Baker, K.F. 1983. The Nature and Practice of Biological Control of Plant Pathogens. American Phytopathological Society, St. Paul, MN.

Gomez, K.A. and Gomez, A.A. 1984. Statistical Procedure for Agricultural Research. John Wiley and Sons, New York.

Latha, P., Anand, T., Prakasam, V., Jonathan, E.I., Paramathma, M. and Samiyappan, R. 2011. Combining Pseudomonas, Bacillus and Trichoderma strains with organic amendments and micronutrient to enhance suppression of collar and root rot disease in Physic nut. Appl. Soil Ecol., 49: 215-223.

Latha, P., Anand, T., Ragupathi, N., Prakasam, V. and Samiyappan, R. 2009. Antimicrobial activity of plant extracts and induction of systemic resistance in tomato plants by mixtures of PGPR strains and Zimmu leaf extract against Alternaria solani. Biol. Control, 50: 85-93.

Li, Y.L. and Wu, W.S. 2002. A new seed-borne pathogen Alternaria dianthicola on Dianthus in Taiwan. Plant Pathology Bulletin, 11: 165-167.

Nandakumar, R., Babu, S., Viswanathan, R., Raguchander, T. and Samiyappan, R. 2001. Induction of systemic resistance in rice against sheath blight disease by plant growth promoting rhizobacteria. Soil Biol. Biochem., 33: 603-612.

Ramakrishnan, G.I., Jayarajan, R. and Dinakaran, D. 1994. Talc based formulation of Trichoderma viride for biocontrol of Macrophomina phaseolina. J. Biol. Control, 8: 41- 44.

Rakshit, A. and Singh, H.B. 2018. Advances in Seed Priming, Springer-Verlag Singapore, ISBN: 96922550, pp. 320.

Ramamoorthy, V., Raguchander, T. and Samiyappan, R. 2002. Enhancing resistance of tomato and hot pepper to Pythium diseases by seed treatment with fluorescent pseudomonads. Eur. J. Plant Pathol., 108: 429-441.
Sen, S. 1996. Occurrence of Alternaria leaf spot and flower blight on marigold (Tagetes erecta) in Himachal Pradesh. Indian Perfumer, 40: 127.

Singh, P.J., Singh, P., Dhindsa, G.S. and Kumar, R. 2006. Efficacy of systemic and non-systemic fungicides against leaf spot (Alternaria tagetica) of marigold. Indian Phytopathol., 59(1): 118-119.

Singh, V.K., Singh, Y. and Kumar, P. 2012. Diseases of ornamental plants and their management, In: Eco-friendly innovative approaches in plant disease management, International Book Distributors and Publisher, New Delhi, pp. 543-572.

Shindhe, M., Narayanaswamy, H., Nagaraja, H. and Murali, R. 2018. Management of leaf spot and flower blight of marigold caused by Alternaria tagetica (Shome and Mustafee) under field condition. Int. J. Chem. Stud., 6(3): 3082-3084.

Thilgavathi, R., Saravanakumar, D., Ragupathy, N. and Samiyappan, R., 2007. Integration of biocontrol agents for the management of dry root rot (Macrophomina phaseolina) disease in greengram. Phytopathol. Mediterr., 46(2): 157-167.

Vidhyasekaran, P., Rabindran, R., Muthamilan, M., Nayar, K., Rajappan, K., Subramanian, N. and Vasumathi, K. 1997. Development of powder formulation of Pseudomonas fluorescens for control of rice blast. Plant Pathol., 46: 291-297. 
